\title{
Pelatihan Tekhnik Dasar dan Sosialisasi Peraturan Permainan Olahraga petanque pada Siswa SMPN 2 Jonggat Lombok Tengah
}

\author{
Andi Gilang Permadi ${ }^{1}$, Muhammad Ridwan Lubis ${ }^{2}$, Rusdiana Yusuf ${ }^{3}$ \\ ${ }^{123}$ Dosen Universitas Pendidikan Mandalika \\ Email : Andigilang@ikipmataram.ac.id
}

\begin{abstract}
Abstrak. Tujuan PKM ini adalah untuk membantu mitra yakni Siswa SMPN 2 Jonggat Lombok Tengah mengatasi permasalahan yang ada. Kegiatan sebelumnya tim sosialisasi mengadakan sosialisasi dan lokakarya petanque dan tahun ini dilanjutkan dengan kegiatan coaching clinic pada sekolah - sekolah yang telah memiliki ekskulikuler petanque di Lombok Tengah yakni SMPN 2 Jonggat. Adapun permasalahan mitra dalam kegiatan PKM adalah kurangnya prestasi sekolah dan kemampuan guru membuat program latihan oleh karena masih kurangnya pengetahuan teknik dasar dan membuat program latihan petanque. Berdasarkan permasalahan mitra maka solusi yang ditawarkan adalah (1) Guru dan Siswa SMPN 2 Jonggat Lombok Tengah lebih memahami olahraga petanque termasuk aturan permainan (2) Pelatih atau guru pembina Ekstrakurikuler lebih mudah dalam pembuatan program latihan. (3) Selain sebagai pendamping siswa dalam bermain, guru juga dapat bertindak sebagai pelatih yang nantinya akan melakukan pembinaan dalam persiapan event Petanque pada Porprov, POPNAS, dan PON. (4) Coaching Clinic pada guru dan siswa dapat berjalan seiring dengan pembinaan, turnamen - turnamen yang akan dilakukan di NTB.
\end{abstract}

\section{Kata Kunci: Tekhnik Dasar, Peraturan Permaianan, Petanque, Siswa Smpn 2 Jonggat Lombok} Tengah

\section{PENDAHULUAN}

Petanque adalah permainan yang bisa dimainkan oleh segala kalangan dan segala usia, yang bisa dimainkan untuk rekreasi bersama keluarga atau teman, dan juga bisa sebagai olahraga prestasi yang dimainkan dalam kejuaraan nasional ataupun internasional. Petanque masuk ke Indonesia pada tahun 2011 yaitu pada saat menjelang seagames 2011 di Indonesia, federasi yang menaungi petanque di Indonesia yaitu FOPI "Federasi olahraga Petanque Indonesia" yang berdiri pada tanggal 18 maret 2011 pada saat itu seluruh atlet dari daerah Palembang karena pada saat itu veneu seagames untuk cabang petanque yaitu terletak di palembang tepatnya di Jakabaring.

Petanque adalah suatu bentuk permainan olahraga yang tujuannya melempar bola besi sedekat mungkin dengan bola kayu yang disebut cochonet. Kaki pelempar juga harus berada di dalam lingkaran kecil yang sudah ditentukan. Ada jarak yang ditetapkan, yaitu jarak lemparan dari bola kayu dengan pelempar, antar enam sampai sepuluh meter. Dalam Petanque, terdapat single tim, double tim, triple tim, dan mix tim, dan jenis permainan ini adalah batle tim. Olahraga Petanque sendiri berasal dari Perancis. Di Perancis, olahraga ini sudah ada sejak sekitar tahun 1907-an. Hampir sebagian masyarakat Perancis memainkan olahraga tersebut. Selain di Perancis, berbagai negara bekas jajahan Perancis juga banyak yang memainkan permainan olahraga tersebut. Petanque pertama kali dipertandingkan di Indonesia pada ajang SEA Games tahun 2011 di Palembang. Di Indonesia terutama Yogya, olahraga ini tergolong baru dan sedang mulai dikembangkan.

Nusa Tenggara barat adalah provinsi terakhir dalam rentang januari - juni 2017 yang berhasil dibentuk kepengurusannya, dimana pengurusnya sebagian besar adalah tenaga 
pengajar di Universitas Pendidikan Mandalika. UNDIKMA diharapkan mampu menjadi sentra pembinaan atlet olahraga petanque. Keberlanjutan permasalahan dalam bentuk Coaching Clinic sangat perlu dilaksanakan mengingat Nusa Tenggara Barat terdiri dari beberapa kabupaten. Fokus permasalahan yang menjadi prioritas dalam pengabdian ini adalah permasalahan mitra SMPN 2 Jonggat yakni peran serta masyarakat dan sekolah dalam event kejuaraan Petanque oleh karena masih kurangnya pelatihan, sosialisasi dan pembinaan di kabupaten - kabupaten provinsi Nusa Tenggara Barat khususnya daerah Lombok Tengah.

\section{METODE PELAKSANAAN}

Berdasarkan hasil identifikasi masalah dan potensi bakat SMPN 2 Jonggat. Beberapan kegiatan yang berkaitan diantaranya adalah sebagai berikut:

1. Peningkatan pengetahuan dan pemahaman mitra tentang teknik dasar permainan olahraga petanque.

2. Peningkatan pengetahuan dan pemahaman mitra tentang peraturan permainan olahraga petanque.

3. Peningkatan pengetahuan dan keterampilan mitra tentang teknik dasar dan peraturan permainan olahraga petanque.

Langkah-langkah yang akan ditempuh pada pelaksanaan pengabdian ini dapat dikemukakan sebagai berikut:

1. Melakukan pembelajaran pengetahuan peraturan permainan dan teknik dasar olahraga petanque secara sistematis bagi Siswa SMPN 2 Jonggat (mitra) metode yang digunakan: ceramah dan tanya jawab.

2. Memperkenalkan gerakan-gerakan aturan permainan dan teknik dasar olahraga petanque bagi Siswa SMPN 2 Jonggat (mitra) metode yang digunakan demonstrasi atau praktek.

3. Menyediakan alat dan perlengkapan untuk melakukan praktek kepada Siswa SMPN 2 Jonggat untuk melakukan gerakan demontrasi.
Bahan dan alat yang dipergunakan dalam pelaksana- an pengabdian ini adalah materi pelatihan Petanque berupa peraturan permainan dan teknik dasar dalam bermain Petanque yang telah disusun semaksimal mungkin, kondisi mitra dan sesuai dengan sasaran yang ingin dicapai dari hasil pengabdian ini.

\section{A. Cara Bermain}

Petanque dimainkan oleh dua, empat atau enam orang dalam dua tim, atau pemain dapat bersaing sebagai individu dan bermain santai. Di tunggal dan ganda permainan setiap pemain memiliki tiga boule. Sebuah koin dilempar untuk menentukan sisi mana pemain bermain terlebih dahulu.Tim mulai menarik lingkaran di tanah yang ber diameter $35-50 \mathrm{~cm}$. Semua pemain harus melempar boule mereka dari dalam lingkaran ini, dengan kedua kaki yang tersisa di tanah. Pemain pertama melempar jack 6-10 meter, setidaknya satu meter dari perbatasan.Pemain yang melemparkan jack kemudian melemparkan boule pertama mereka. Seorang pemain dari tim lawan kemudian membuat melempar. Bermain terus dengan tim yang tidak terdekat ke jack harus terus melemparkan tanah sampai mereka boule lebih dekat ke jack dari lawan mereka atau kehabisan boule. Jika boule terdekat dari setiap tim adalah jarak yang sama dari jack, maka tim yang memainkan memainkan terakhir lagi. Jika boule masih berjarak sama maka tim bermain bergantian sampai perubahan posisi. Jika boule masih berjarak sama pada akhir pertandingan maka tidak ada poin yang dicetak oleh tim baik. Permainan berlanjut dengan pemain dari tim yang memenangkan akhir sebelumnya menggambar lingkaran baru di sekitar dimana jack selesai dan melemparkan jack untuk akhir yang baru.

Permainan berakhir, dan titik dapat mencetak gol ketika kedua tim tidak memiliki boule lebih, atau ketika jack adalah tersingkir dari bermain. Tim yang menang menerima satu poin untuk setiap boule yang telah lebih dekat ke jack dari boule terbaik-ditempatkan oposisi. Jika jack terlempar dari arena 
permainan, tidak ada skor tim kecuali hanya satu tim telah boule kiri untuk memutar. Dalam hal ini tim dengan boule menerima satu poin untuk setiap bahwa mereka harus bermain. Tim pemenang adalah yang pertama yang mencapai 13 poin kemenangan.

B. Perlengkapan dan Lapangan Petanque

Peralatan yang digunakan dalam pertandingan petanque harus memenuhi syarat international dan dibuat oleh manufaktur resmi organisasi dunia olahraga petanque. Syarat ini meluputi berat bola, ukuran tangan, bahan material, merek dan nomor seri. Adapun alat tersebut adalah:

1. Bosi merupakan bola berbentuk bulat terbuat dari logam dan berongga dibahagian dalamnya, mempunyai garis pusat antara 70,5-80 $\mathrm{mm}$ dan beratnya antara 650-800 g. Disamping itu, biasanya boule ini mempunyai nama tertentu, angka penunjuk berat dan nomor seri.

2. Boka atau Jack merupakan bola yang terbuat dari kayu. Boka mempunyai garis pusat antara 25-35 $\mathrm{mm}$ bola ini harus berwarna dan mudah dilihat pada lapangan permainan.

3. Meteran adalah meteran pengukur untuk jarak $1 \mathrm{~m}, 5 \mathrm{~m}$ dan $10 \mathrm{~m}$.

4. Lingkaran berdiameter $50 \mathrm{~cm}$ digunakan untuk sebagai penanda untuk pemain mulai melakukan tembakan dalam permainan petanque.

5. Scoring adalah alat yang digunakan untuk mencatat poin dalam pertandingan petanque

6. Selain alat pertandingan petanque, juga mem- butuhkan lapangan.

Berdasarkan FIPJP, standar internasional dan nasional ukura ukuran $15 \mathrm{~m}$ x $4 \mathrm{~m}$ atau $13 \mathrm{~m} \times 3 \mathrm{~m}$. Petanque dapat dimainkan di atas tanah liat atau berbatuan, untuk lapangan rumput dan lapangan concrete tidak direkomendasi.

C. Teknik Dasar dalam Permainan Petanque

Teknik dasar dalam permainan

petanque meliputi:

memegang bosi, posisi kaki dan posisi melempar.

1. Teknik dasar memegang bola diawali dengan teknik memegang bola mengahadap ke atas dan menghadap ke bawah seperti terlihat pada Gambar 1.

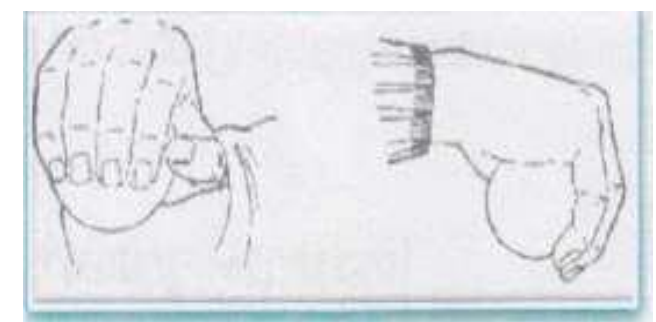

\section{Gambar 1.Teknik dasar memegang bola petanque}

2. Posisi kaki, Posisi kaki dalam permainan petanque memerlukan teknik khusus. Ada tiga jenis posisi kaki yaitu posisi tertutup, posisi kaki semi terbuka, dan posisi kaki terbuka. Adapun posisi kaki tersebut seperti pada Gambar 2.

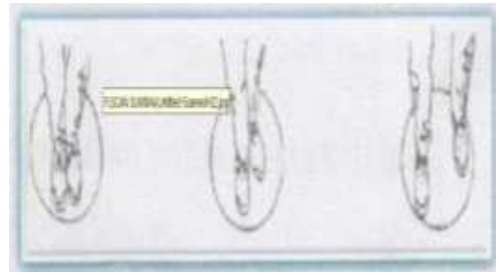

\section{Gambar 2. Posisi kaki dalam petanque}

3. Posisi melempar ada empat jenis posisi melempar yaitu melempar dengan posisi jongkok, melempar dengan posisi setengah jongkok, melempar dengan posisi berdiri dan melempar dengan posisi high lop. Adapun ke empat posisi melempar tersebut seperti dalam Gambar 3.

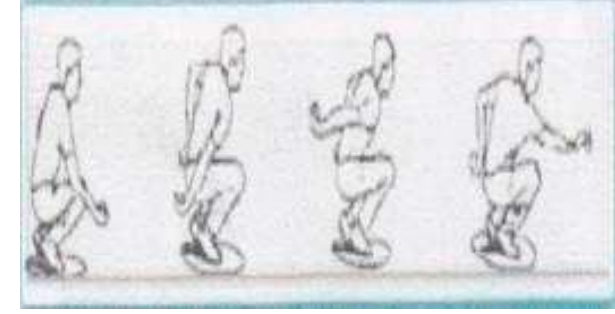

Gambar 3. Melempar posisi jongkok 


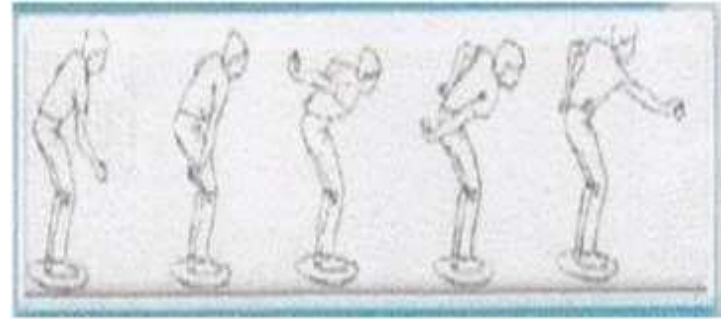

Gambar 4. Melempar posisi berdiri

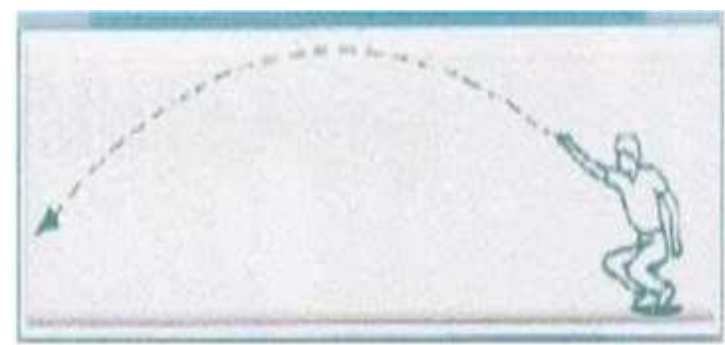

Gambar 5. Melempar posisi setengah jongkok

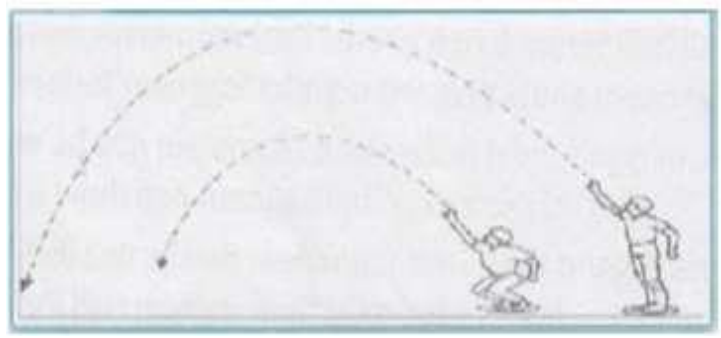

Gambar 6. Melempar posisi high lop

D. Teknik Lemparan

Ada dua jenis lemparan dalam olahraga petanque yaitu :

1. Pointing adalah jenis lemparan untuk mendekati boka target lebih dekat dari bosi lawan. Ada beberapa cara melakukan pointing yaitu:

a. Roll (menggelinding) yaitu melempar bola

kurang dari 3 meter dari lingkaran dimana bosi tersebut menggelinding sepanjang arena mendekati bola target.

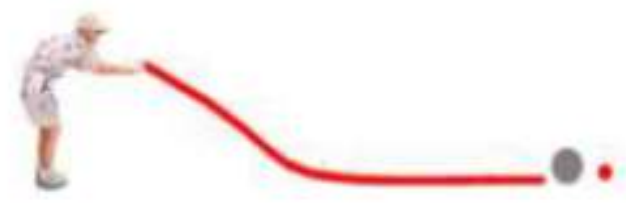

Gambar 7. Teknik pointing roll

b. Soft lob (melambung sedang) yaitu melempar bosi sedikit lebih tinggi membentuk kurva dan bosi jatuh dan menggelinging ke boka target.

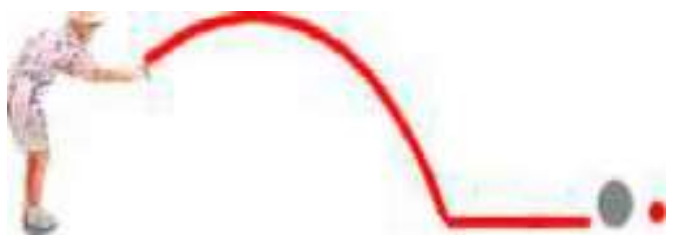

Gambar 8. Teknik pointing soft lob

c. Full lob (melambung tinggi) melempar bola lebih tinggi hampir vertical dan bosi jatuh dan menggelinding ke boka target.

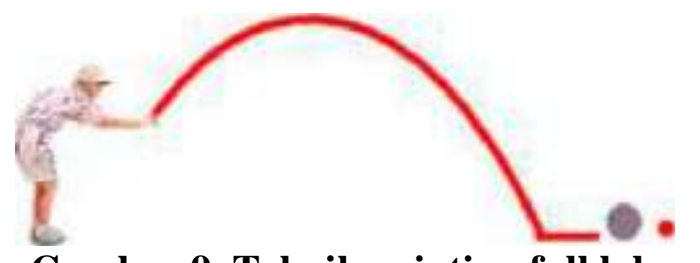

Gambar 9. Teknik pointing full lob

2. Shooting adalah jenis lemparan untuk mengusir bosi lawan dari boka target. Ada beberapa cara melakukan shooting yaitu:

a. Shot on the iron (bosi ke bosi) adalah menembak tepat pada bosi lawan tanpa menyentuh tanah terlebih dahulu.

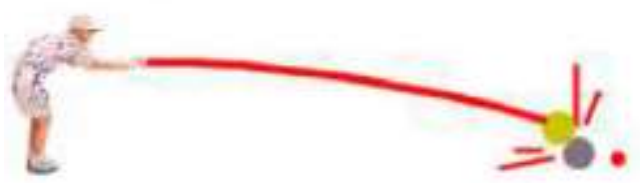

Gambar 10. Shooting shot on the iron 2

b. Short shot adalah menembak bosi lawan dengan terlebih dahulu menyentuh tanah sekitar 20 sampai dengan $30 \mathrm{~cm}$ dari boka target. 


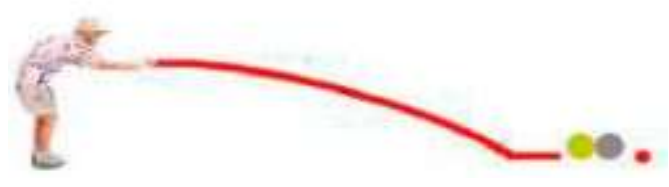

\section{Gambar 11. Shooting short shot 3}

c. Ground shot adalah menembak bosi lawan dengan terlebih dahulu menyentuh tanah sekitar 3 atau 4 meter dan menggelinding mengenai boka target.

\section{HASIL DAN PEMBAHASAN}

Kesempatan yang sangat berharga ini tidak disia- siakan walau disadari bahwa mulai dari sarana dan peralatan kegiatan ini sangatlah terbatas.Tetapi dengan semangat yang kuat dan dorongan dari PENGPROV FOPI NTB dan guru olahraga di sekolah, menjadikan kegiatan ini menjadi kegiatan yang bermanfaat. Siswa juga mendapat pengetahun baru tentang olahraga petanque ini dan siswa juga dapat menenkuni olahraga ini agar nantinya bisa mewakili sekolah bahkan daerah untuk bisa ikut berpartisipasi di kejuaraan yang di selenggarakan oleh PENGPROV FOPI NTB sendiri atau bahkan event yang dilaksanakan oleh PB FOPI pusat

Dengan diselenggarakan pelatihan ini siswa dan guru khususnya guru olahraga mempunyai pengetahuan serta keterampilan sebagai berikut:

1. Seluruh siswa mendapat pengetahuan yang cukup tentang peraturan permainan dan teknik dasar olahraga petanque yang akan dilakukan.

2. Seluruh siswa mendapat pengetahuan dan keterampilan bermain petanque yang cukup baik dalam melakukan olahraga petanque.

3. Seluruh siswa mendapat pemahaman tentang pentingnya peraturan permainan dan teknik dasar olahraga petanque yang benar terhadap peningkatan kualitasolahraga petanque.

\section{KESIMPULAN}

Abdi Masyarakat
Dari pelaksanaan kegiatan pelatihan yang dilaksanakan dengan judul : pelatihan peraturan permainan dan teknik dasar olahraga petanque siswa SMPN 2 Jonggat Lombok Tengah, dapat diambil kesimpulan sebagai berikut:

1. Materi pelatihan sangat diminati oleh seluruh siswa dan mudah dipahami serta dilakukan dengan serius karena telah melihat contoh yang telah diberikan dari tekhnik dasar dan peraturan permainan

2. Peserta dapat menerima materi dengan bersemangat dan kemauan yang besar sehingga materi pelatihan dapat diserap oleh seluruh siswa dengan baik.

3. Motivasi siswa cukup tinggi mengikuti pelatihan sampai selesai.

4. Siswa menyadari bahwa materi yang diberikan adalah pengetahuan tambahan yang sangat bermanfaat bagi mereka untuk dapat tetap bersemangat menjalani latihan Petanque secara rutin untuk mendapatkan prestasi.

\section{DAFTAR PUSTAKA}

Barr KP, Griggs M, Cadby T. 2005. Lumbar Stabilization, Core Concept And Current

Literature, part 1: American Journal of Physical Medicine \& Rehabilitation Copyright: $\quad 473-480$ by Lippincott Williams\&Wilkins

CMSB. 2015. Petanque, (online), (http://www.cmsboules.org/index.php/ en /petanque,)diakses tanggal 5 Maret 2019.

FIPJP, 2010. The official rules of the game of Petanque. Turkey : Izmir

Paor.2017.

(Online) htttp://paolahraga.blogspot.com/2017/ 11 /perlengkapan-dan peraturanpetanque. html. Diakses tanggal 10 Maret 2019

Pengurus Besar Federasi Olahraga Petanque Indonesia. (2012). Program dan Teknik

Dasar Bermain Petanque. Jakarta. 